\title{
Affinities of the Australian Paper Wasp Ropalidia proletaria (Insecta: Hymenoptera: Vespidae), with Descriptions of Males, Mature Larvae, and a Nest
}

\author{
Jun-ichi Kojima \\ Natural History Laboratory, Faculty of Science, Ibaraki University, \\ Mito, 310-8512 Japan \\ E-mail: jkrte@mito.ipc.ibaraki.ac.jp
}

(Received 20 May 2000; Accepted 22 September 2000)

\begin{abstract}
The males, mature larvae, and a nest of an Australian paper wasp, Ropalidia proletaria Richards, 1978, are described for the first time. Not only the female adult morphology but also the morphologies of the male, larva, and nest suggest that $R$. proletaria is closely related to $R$. plebeiana Richards, 1978 , rather than to $R$. revolutionalis (de Saussure, 1853) as Richards (1978) suggested.
\end{abstract}

Key Words: Vespidae, Polistinae, Ropalidia proletaria, male, larva, nest, $R$. plebeiana.

\section{Introduction}

Richards (1978, p. 96), in his monograph of Australian social wasps, described Ropalidia proletaria based on three females from "North Queensland" and a female from "? Port Darwin" (all deposited in The Natural History Museum, London) and mentioned that $R$. proletaria was "Very close to $R$. revolutionalis" (p. 97). I elsewhere (Kojima 1999a) recorded a female from " $5 \mathrm{~km}$ SW of Kuranda" (deposited in the Australian National Insect Collection, CSIRO, Canberra) and noted that $R$. proletaria seemed to be closer to $R$. plebeiana Richards, 1978 than to $R$. revolutionalis (de Saussure, 1853). These five females have been the only available specimens of $R$. proletaria.

Recently I had a chance to collect a nest of $R$. proletaria, which provided me the material to discuss the relationships among $R$. proletaria, $R$. plebeiana, and $R$. revolutionalis based on the morphologies of the adults (both female and male), larvae, and nests.

\section{Materials and Methods}

A live nest made on a leaf of a guava tree (Psidium guajava Linnaeus, 1753) at $1.5 \mathrm{~m}$ above the ground was collected with three adult females in an orchard at Julatten $\left(16^{\circ} 37^{\prime} \mathrm{S}, 145^{\circ} 21^{\prime} \mathrm{E}\right)$, northern Queensland, Australia, on 9 March 2000 . The nest consisted of a single comb of 54 cells (Fig. 1A), most of which were filled with immature individuals (Fig. 1B). The larvae in the nest were taken out and preserved in $70 \%$ ethanol for later observation. Then the nest was kept in a small plas- 

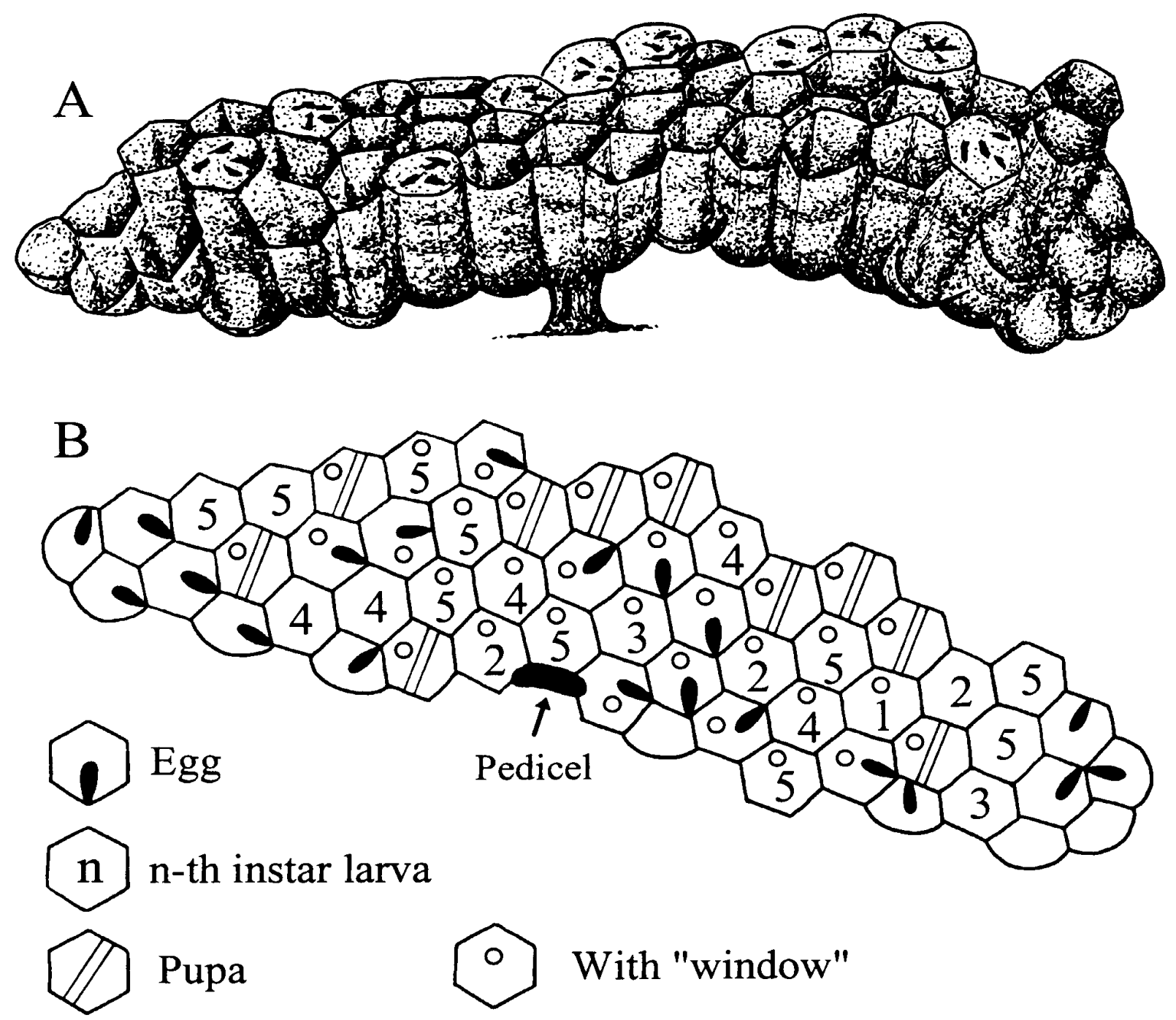

With "window"

Fig. 1. Lateral view of the nest of Ropalidia proletaria (A) and the disposition within it of immature stages (B).

tic box and two adult males emerged; the other pupae died.

The adult females were dissected for spermathecae and ovaries, and then pinned. The adult morphology except for the male genitalia was observed on pinned specimens under a stereoscopic dissecting microscope. The male terminal sterna and genitalia were dissected out, briefly cleared in $\mathrm{KOH}$, and mounted on glass slides in glycerin to observe under both a stereoscopic dissecting and a compound microscope. The terminology of the male genitalia follows Kojima (1999b).

Coloration of mature larvae was observed on specimens in $70 \%$ ethanol under a stereoscopic dissecting microscope; then four mature larvae were cleared in hot $\mathrm{KOH}$ and heavily stained with acid fuchsin. They were dissected and mounted on glass slides in Canada balsam to observe microscopic structures under a compound microscope. The terminology of the larval morphology follows Kojima (1998).

Observations of nest characters, including the measurement of various parts with vernier calipers to the nearest $0.05 \mathrm{~mm}$, were conducted after the nest had 
been air-dried.

One female, one male, and two mature larvae are deposited in the Australian National Insect Collection, CSIRO, Canberra, and the remaining specimens including the nest are deposited in the Natural History Laboratory, Ibaraki University.

\section{Descriptions}

\section{Adult female}

One of the three females collected was inseminated and had developed ovaries; another female was uninseminated and had filamentous ovarioles. The remaining female was parasitized by three strepsipterans found between the third and fourth, fourth and fifth, and fifth and sixth metasomal terga, respectively; this specimen was not dissected to check the conditions of its spermatheca and ovary.

The structure and marking pattern generally agreed with the original description by Richards (1978), but there were considerable discrepancies in some morphometric characters. Richards (1978) did not define the parts that he measured and discrepancies between the values given in the text and those estimated from the figures are not rare in his monograph; e.g., the length/width ratio of the second metasomal segment in R. plebeiana is "c. 1.7" (p. 77) in the text, while less than 1.2 in the figure (p. 85); the latter value agrees with my own observations. The three females are described below, and the descriptions of Richards (1978) are cited in brackets when there are distinct differences; although I have only briefly examined the holotype in The Natural History Museum, the specimen generally agrees with my three specimens rather than with the original description by Richards.

Body length (head + mesosoma + first two metasomal segments) $8.5-9.5 \mathrm{~mm}$; forewing length 7 [7.0-8.5] $\mathrm{mm}$.

Head in frontal view (Fig. 2) about 1.15 times as wide as high; in dorsal view (Fig. 3) about twice as wide as long, weakly narrowed behind eyes, shallowly emarginate posteriorly, and about as wide as mesosoma including tegulae. Ocelli arranged in nearly equilateral triangle; anterior ocellus slightly larger than posterior ones; distance between latter about $1.8 \times$ their diameter and about $0.6 \times$ distance from posterior ocellus to eye. Inner eye margins weakly converging ventrally; distance between them at vertex about 1.2 times as wide as that at clypeus. Clypeus weakly convex, pointed below, about 1.4 times as wide (excluding lateral lobes) as high (measured from bottom of dorsal emargination to apex) [about 1.5 times as wide as high; but parts measured were not defined]. Mandible normal, not twisted. Gena in profile (Fig. 4) weakly widening ventrally to level of mid-height of eye, then slightly narrowing farther ventrally, about 0.8 (range $0.75-0.85$ ) times as wide [nearly as wide] as eye; occipital carina complete, fine, smoothly and weakly curved. Malar space distinctly shorter than [nearly as long as] width of antennal socket. Antenna as in Fig. 5; scape slightly curved, about 4 times as long (excluding radicle) as wide; flagellum weakly thickened apically; tenth or eleventh article widest, about 1.5 times as wide as third article; third article about 2.5 times as long as its own apical width, somewhat longer than length of fourth and fifth articles combined; fourth article about as long as wide; each of fifth to eleventh articles wider than long; terminal article nearly bullet-shaped, slightly more than 1.1 times as long as wide at base. 


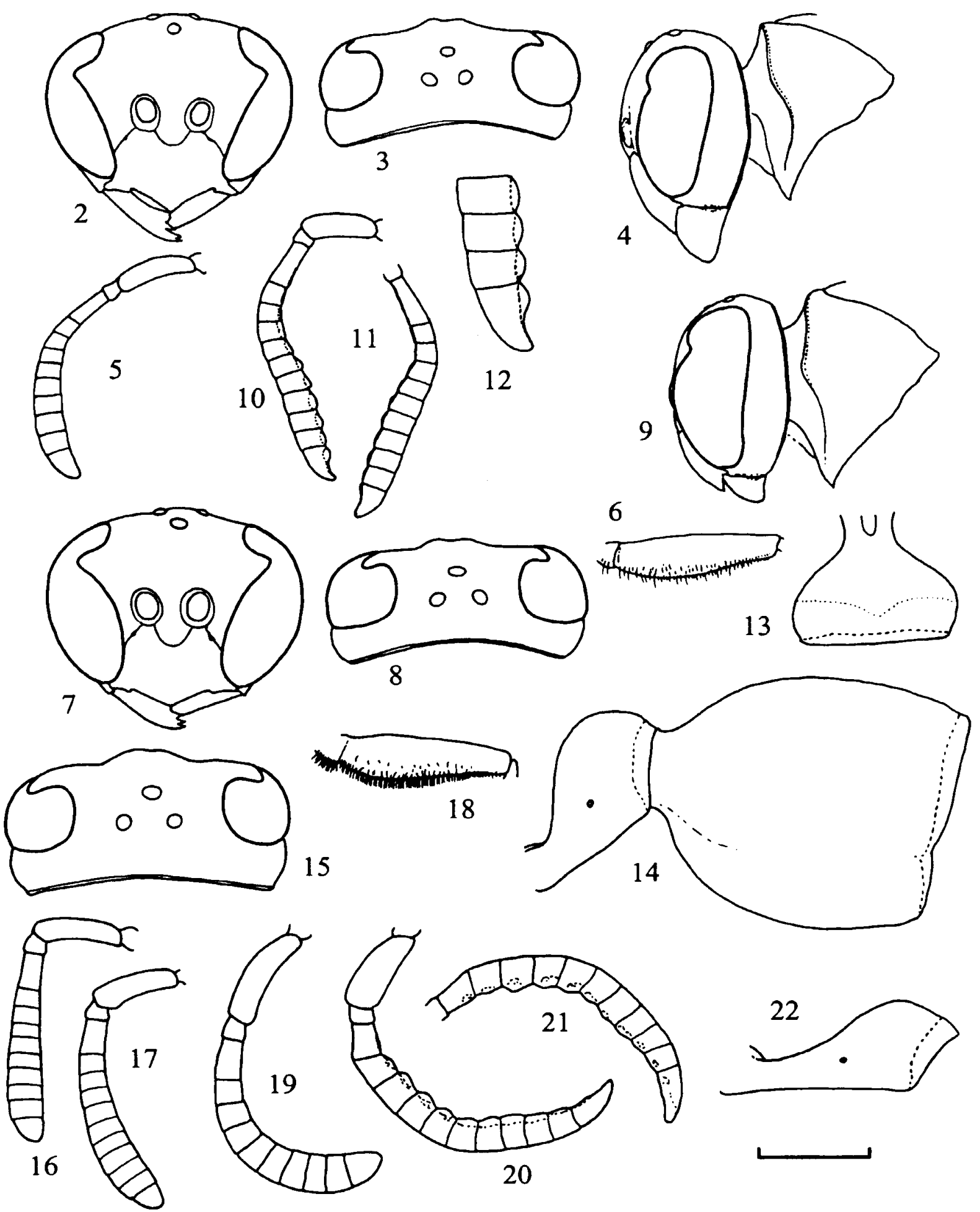

Figs 2-22. Characters of Australian Ropalidia species. 2-14, $R$. proletaria; 15-18, $R$. revolutionalis; 19-22, R. plebeiana. 2-6, 15-16, 18, 19, Female; 7-14, 17, 20-22, male. 2, 7, Head in frontal view; $3,8,15$, head in dorsal view; 4, 9, head and pronotum in lateral view; 5, 10-12, 16-17, 19-21, right antenna; 6,18 , mid femur; 13, first metasomal tergum in dorsal view; 14, first and second metasomal segments in lateral view; 22, first metasomal segment in lateral view. Scale line: $1 \mathrm{~mm}$, but $0.5 \mathrm{~mm}$ for 12 . 
Mesosoma about 1.4 times as long as wide. Pronotum in dorsal view with anterior margin weakly rounded; lateral sides slightly concave and weakly diverging posteriorly; pronotal carina complete, raised into low lamella, and rather strongly raised and posteriorly sinuate at humeral angles (Fig. 4). Scutum weakly convex, about as long as wide. Disc of scutellum trapezoid, convex, very shallowly concave medially, and with weak carina along lateral margin. Disc of metanotum nearly flat, with lateral marginal carina, and barely produced posteriorly. Propodeum with wide median concavity showing little posterior narrowing; posterior face in profile sloping down in nearly straight line in dorsal two thirds, then broadly angled and becoming vertical; propodeal orifice rounded above, about twice as long as wide; propodeal valvula not large (in profile propodeal teeth surrounding orifice partly visible), with broadly rounded trianglular outline and marginal carina at base.

First metasomal segment short; about 1 to 1.2 times as long (measured in profile from posterodorsal corner to posterior margin of basal slit corresponding to mesosomal suspensory ligament) as maximum width of tergum (Figs 13-14; these figures for male, but states same in female); tergum in dorsal view (Fig. 13) strongly widened posteriorly after short, basal, parallel-sided part about [twice] as long as wide, then weakly constricted near apical margin; widened posterior part in dorsal view hemispherical, less than 1.5 times [twice] as wide as long, and about 3.5 times as wide as basal, parallel-sided part; dorsal face of tergum in profile rising steadily in nearly straight line from posterior margin of basal slit, then broadly rounded, and weakly depressed at posterior lamella; posterior lamella narrow medially, weakly dilated on both sides of middle, then narrowing at lateral margins (Fig. 14); in ventral view, ventral margins of tergum weakly approaching each other before posterior divergence; sternum barely emarginate posteriorly. Second metasomal segment about as long as or slightly shorter or longer than [1.5 times as long as] wide, and 1.1 to 1.2 times as long as high; about 1.85 times as wide as maximum width of first tergum, and about twice [3 times] as wide as latter's apical width; suture between tergum and sternum hardly visible; posterior lamella rather wide, depressed; articulation of tergum separated from short "neck" by punctures.

Head with dense punctures, appressed tomentum, and sparse suberect setae; ventral one-third of clypeus polished, without tomentum, and with sparser and shallow punctures. Mesosoma covered with dense punctures similar to those on head, and with shorter tomentum and sparse setae; posterior triangular area of metanotum polished, without punctures, tomentum, or setae, not reaching anterior margin of segment; border between punctured posterodorsal and unpunctured anteroventral areas of mesepisternum distinct but not carinate; median concavity of propodeum with shallow, ill-defined punctures and with fine, transverse striae medially. Mid femur with short and rather sparse [dense, even] ventral fringe of tomentum, with sparse setae protruding from it (Fig. 6). Metasoma covered with dense, appressed tomentum; first metasomal tergum with dense punctures posteriorly, nearly no punctures in anterior half; second segment with punctures less dense than on mesosoma, each puncture ill-defined posteriorly.

Head dark ferruginous; facial sutures, area around ocelli with ill-defined branches running toward antennal sockets, spot above each antennal socket, posteroventral margin of gena, and occipital carina, black; reverse triangular spot be- 
tween antennal sockets, wide band along inner orbit (sometimes reduced), large basal spot on mandible, yellow; clypeus yellow, except large median blackish spot connected with dorsal emargination (sometimes reduced); antenna ferruginous, largely yellow ventrally. Mesosoma black; dorsal side and ventral parts of pronotum, ill-defined paired longitudinal median bands and spots inside tegulae on scutum, disc of scutellum (with median narrow black band), and disc of metanotum, dark ferruginous; wide band along pronotal carina, pair of large, lateral spots on discs of scutellum and metanotum, and scrobal spot (dark ferruginous ventrally), yellow; tegulae yellow, with outer semitransparent ferruginous spot. Wings yellowish brown, costal margin darker. Legs ferruginous; coxae, trochanters, and basal parts of femora, black or blackish brown; ventral faces of fore and mid coxae yellow. First metasomal tergum dark ferruginous, black basally, and with wide, pre-apical, yellow band; second to terminal metasomal segments nearly black, with yellow apical band; second segment sometimes dark ferruginous basally and apically; most visible part of terminal segment yellow.

\section{Adult male}

Body length (head + mesosoma + first two metasomal segments) $8-9 \mathrm{~mm}$; forewing length $7 \mathrm{~mm}$.

Structure and coloration as in female but: most ferruginous markings of head replaced with black; scutellum entirely black, or ferruginous marks darker than in female. Head more transverse, about 1.25 times as wide as high (Fig. 7); eye more strongly swollen, inner margins more distinctly convergent ventrally, distance between them at vertex about 1.3 times as wide as that at clypeus; clypeus smaller, much less convex, about 1.5 times as wide as high, covered with tomentum except at apical margin. Distance between posterior ocellus and eye longer, about $1.7 \times$ distance between posterior ocelli. Gena narrower (Figs 8-9), about 0.65 time as wide as eye in profile. Antennal scape shorter (Figs 10-11), weakly swollen medially, slightly less than 3 times as long (excluding radicle) as wide; third article about 2.6 times as long as wide at apex, distinctly longer than fourth and fifth articles combined, each of latter as long as wide; terminal article (Fig. 12) about 1.5 times as long as wide at base, slightly swollen ventrally in basal one fourth, excised ventrally in apical three fourths, with narrowly rounded apex; flagellum flattened ventrally, or slightly concave on ninth to twelfth antennal articles; tyloids present at posterior margin of flattened ventral side of all flagellar articles; that on third antennal article weakly raised linear ridge, slightly widened apically; that on terminal article strongly raised in basal part of article, then modified into flat, shiny, narrow band apically.

Terminal sterna and genitalia as in Figs 23-28. Parameral spine without hairs; Parameral Spine Index of Charnley (1973): (length of projection beyond lobe)/(total length of paramere and spine) $\times 100=23$. Volsella as in most Ropalidia species (see Kojima 1999b). Penis valves about 0.85 times as long as basal apodeme; in profile, apical part strongly curved ventrally.

\section{Mature larva}

Cranial width $1.65-2.05 \mathrm{~mm}(\mathrm{n}=10)$.

Cranium dark grayish brown (Fig. 29); ventral part of clypeus unpigmented; ecdysial sulcus, parietal band (partly), and ill-defined spot around antenna pale 

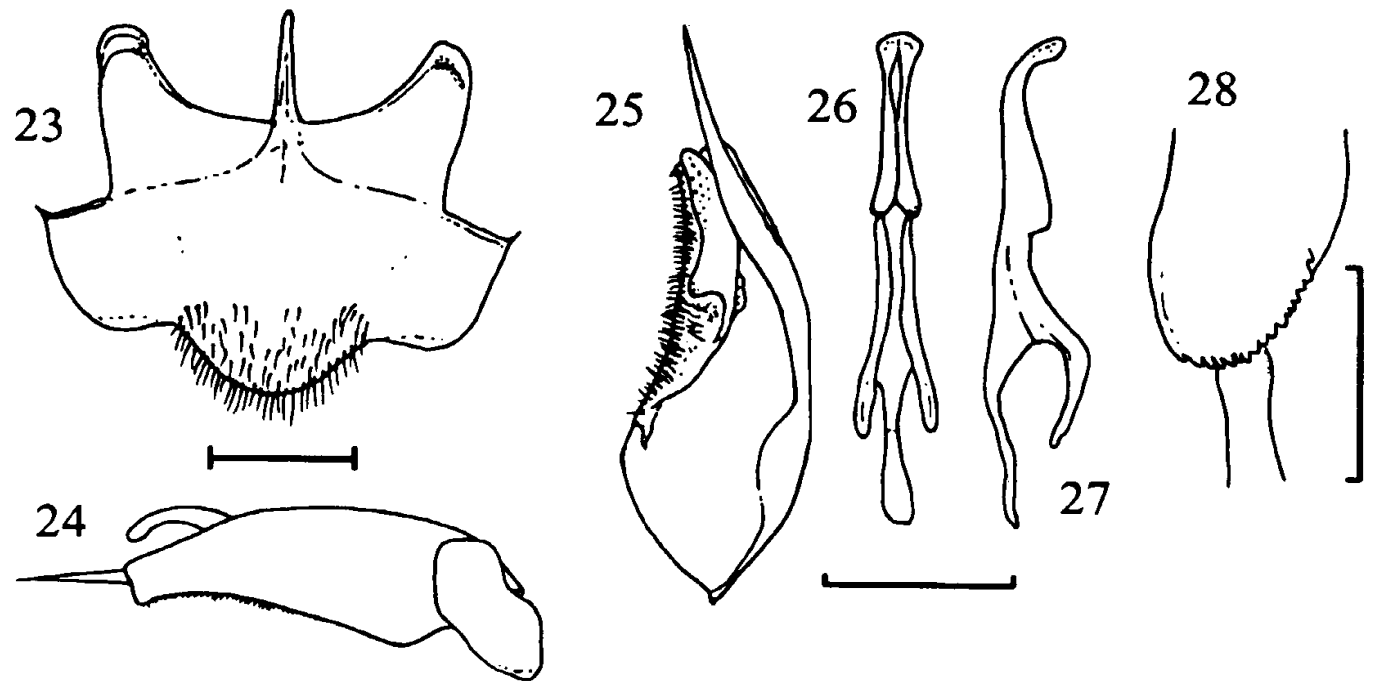

Figs 23-28. Male terminal sterna (23) and genitalia (24-28) of Ropalidia proletaria. 24, Phallic capsule in lateral view; 25, inner aspect of paramere with volsella and digitus; 26-27, aedeagus in ventral (26) and lateral (27) views; 28 , proximal part of penis valve in ventral view. Scale lines: $0.5 \mathrm{~mm}$ for $23-27$, and $0.1 \mathrm{~mm}$ for 28 .

brown. Mouthparts unpigmented, but mandibles pale brown, with teeth colored orange-brown; irregular spots near lateral margin of maxilla and lower half of prementum dark brown; conical papillae on labrum and palate, galea, and maxillary and labial palpi dark grayish-brown. Body unpigmented.

Cranium in frontal view broadly rounded dorsally (Figs 29-30), widest slightly above level of antennae, with lateral sides slightly convex and weakly converging ventrally, about 1.3 times as wide as high; in lateral view (Fig. 31) deeply emarginate posteriorly; integument with scattered minute punctures, each bearing minute seta; ventral part of clypeus more weakly sclerotized than other parts of cranium. Outer one-third of parietal band weakly reticulate. Ecdysial sulcus present only in upper part. Antenna small, widely separated from anterior tentorial pit, with 3 minute sensilla, 2 of latter located very close to each other. Clypeus about 0.55 times as wide as maximum width of cranium. Labrum (Fig. 32) slightly narrowed at junction with clypeus, nearly as wide as clypeus, with 10 to 15 small punctures bearing minute setae. Palate (Fig. 33) with about 20 conical papillae medioventrally, several minute setae dorsally, and spicules along lateral and ventral margins. Mandibles (Fig. 34) slightly crossed when closed, bi-dentate; subsidiary tooth short, about one third as long as main tooth. Maxilla weakly swollen laterally, with sclerotized basal ring; upper surface covered with dense spicules; apical part sometimes with 1 to a few minute setae; maxillary palpus (Fig. 35) with flat apex, bearing 4 sensilla; galea deeply bi-lobed, each lobe with 1 apical sensillum. Prementum subcircular but weakly produced ventrally, with about 45 scattered, minute setae in area below level of labial palpi; labial palpus (Fig. 36) similar to maxillary palpus, with 4 apical sensilla; paired setae behind palpi short, with strongly raised sockets; area between palpi with very sparse, minute spicules. Postmentum developed, deeply emarginate ventrally (Fig. 30), with several short setae dorsally, and without spicules.

Spiracular atrium bare; first spiracle about twice as wide in diameter as re- 

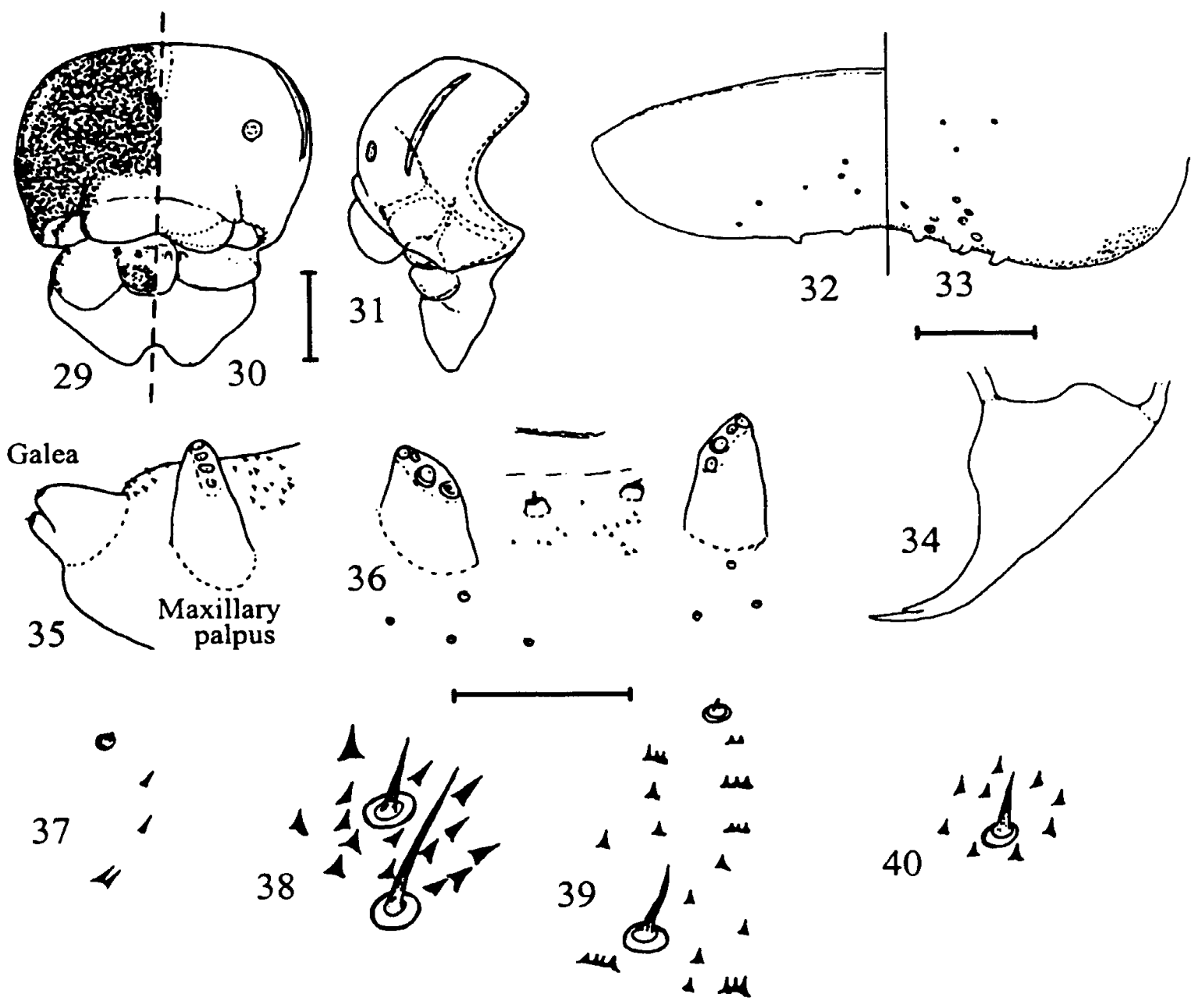

Figs 29-40. Mature larva of Ropalidia proletaria. 29-30, Head in frontal view (29, marking pattern; 30, external structure); 31, head in lateral view; 32, labrum; 33, palate; 34, left mandible; 35 , apical part of left maxilla; 36, labial palpi and structures around them; 37-40, setae and spicules in anterolateral part of venter of first thoracic segment (37), on venter of first (38) and second (39) abdominal segments, and on dorsum of second thoracic segment (40). Scale lines: $0.5 \mathrm{~mm}$ for $29-31,0.2 \mathrm{~mm}$ for $32-34,0.1 \mathrm{~mm}$ for $35-36$, and $0.05 \mathrm{~mm}$ for $37-40$.

maining ones. Each body segment with setae arranged in median transverse band; setae on venter of second thoracic to first abdominal segments (T2-A1) long (Figs 38-39). T1 venter bare anteromedially; armed anterolaterally with sparse, minute setae and sparse, fine spicules, latter sometimes joined at their bases (Fig. 37); armed posterolaterally with dense spicules, and scattered spicules between leg-bud plates. T2 venter bare anteromedially, with dense, large spicules posteromedially and laterally (Fig. 38). T3 and A1 venters entirely covered with dense spicules similar to those on T2 venter; A2-A9 venters with spicules becoming smaller and sparser toward posterior segments, and A10 venter nearly without spicules; spicules on A2-A4 venters often contiguous, forming bi- to quadri-dentate ridges (Fig. 39). Dorsal lobes bare; dorsum of body integument covered with spicules, densely on anterior segments (Fig. 40) and more sparsely and smaller toward posterior segments. 


\section{Nest}

The nest (Fig. 1) consisted of a single exposed comb made on the upper side of a guava leaf, which was curled up over the comb; the comb was generally parallel to the leaf surface, and thus the cells opened obliquely upward. Bases of pupal cells and cells having produced adults had semitransparent "windows" made of adults' oral secretion; judging from the brood composition and the presence of "windows," cells were added on only one side of the pedicel in an earlier stage of nest development, then bilaterally. Other characters as follows: nest material consisting of chips of plant fibers mixed with rather large amount of oral secretion; pedicel and back of comb around it grayish to dark brown due to coating of oral secretion; cell walls with stripes of different colors, pale to dark gray and grayish brown. Pedicel single, column-shaped, $2.7 \mathrm{~mm}$ long, $1.7 \mathrm{~mm} \times 2.7 \mathrm{~mm}$ thick near mid-length, enlarged with plant fibers, thinly coated with salivary secretion. Comb $45 \mathrm{~mm} \times$ $13 \mathrm{~mm}$; back nearly flat. Cells hexagonal, arranged regularly, hardly divergent at all towards open ends; minimum diameter and length of pupal cells $3.2 \mathrm{~mm}(\mathrm{n}=5$, range $3.05-3.35 \mathrm{~mm})$ and $9.7 \mathrm{~mm}(\mathrm{n}=5$, range $8.0-10.2 \mathrm{~mm})$, respectively; shallow peripheral cells with their free margins rounded, but longer peripheral cells hexagonal like central cells. Cocoon caps dark brown, barely to strongly $(1.8 \mathrm{~mm})$ produced beyond cells, with blots of chips of plant fibers.

\section{Discussion}

Ropalidia revolutionalis belongs to the $R$. variegata group. Synapomorphies for this species group are as follows (Kojima and Carpenter unpublished): posterior margin of vertex barely emarginate medially (Fig. 15); sexual dimorphism in antennae weak (Figs 16-17); male antenna without tyloids (Fig. 17); mid femur with dense, even, ventral fringe of tomentum (Fig. 18); penis valve short (see Kojima 1999b); and nest comb slender and vertically hanging from single terminal petiole. Furthermore, a mono-dentate larval mandible seems to be a synapomorphy for the $R$. variegata group $+R$. fasciata group, although this character shows considerable homoplasy (see Kojima 1998). The condition of the posterior margin of the vertex in $R$. proletaria approaches that in the $R$. variegata group, while the states for the other characters do not suggest a close relationship of this sort. On the other hand, the following characteristics that seem to be derived in the genus Ropalidia are shared by $R$. proletaria and $R$. plebeiana: first metasomal tergum with posterior lamella narrowing at lateral margins (Figs 13-14, 22); male antenna with developed tyloids (Figs 10-12, 20-21); and terminal article of male antenna excised ventrally (Figs 12, 20-21). The nest petiole enlarged with plant fibers, not strictly by adult salivary secretion, is also presumably a derived condition in the genus Ropalidia and found in both species. Ropalidia proletaria and $R$. plebeiana are likely to form a natural group, but its phylogenetic positions in the genus is yet unclear.

Richards (1978) described Ropalidia hirsuta based on three female specimens from "Port Darwin" in Australia's Northern Territory. I elsewhere synonymized $R$. hirsuta under $R$. plebeiana and doubted if some of the types of $R$. hirsuta were correctly labeled (Kojima 1999a). The collector of these specimens was R. C. L. Perkins, who also collected all the types of $R$. proletaria. Richards (1978) listed specimens of $R$. socialistica (de Saussure, 1853) and $R$. trichophthalma Richards, 
1978 from "Port Darwin" collected by R. C. L. Perkins but doubted that these specimens had been correctly labeled; as for the paratype of $R$. proletaria from "Port Darwin," he put a question mark in front of the locality name. Recent reliable records suggest that $R$. plebeiana is distributed along the eastern coast of Australia from Victoria in the south to northern Queensland in the north, and that $R$. proletaria is restricted to northern Queensland (Kojima 1999c).

The other 19 species of Ropalidia known from Australia can be divided into three groups in terms of their distributional patterns (Kojima 1999c): (1) 12 species that are restricted to the eastern part of the continent and occur also in New Guinea or have closely related species endemic to New Guinea; (2) the species in the $R$. variegata group ( $R$. revolutionalis, $R$. interrupta van der Vecht, 1941, and $R$. flavinoda van der Vecht, 1941) and the $R$. stigma group ( $R$. elegantula Richards, 1978 and $R$. darwini Richards, 1978), which occur at the species-group level in Queensland and the Northern Territory, with closely related species distributed from India to the Lesser Sunda Islands, but not in New Guinea; (3) $R$. romandi (Le Guillou, 1841) and $R$. impetuosa (Smith, 1860) (=R. "gregaria" of authors) are also distributed in Queensland and the Northern Territory, while R. impetuosa and species related to $R$. romandi occur both in New Guinea and Southeast Asia. Ropalidia proletaria and $R$. plebeiana have a distributional pattern similar to that of the first group, but no species known from New Guinea seems to be closely related to either of them. Further phylogenetic and biogeographic studies of Australian and Papuan Ropalidia could shed light on the speciation process and biogeography of this genus in Australia.

\section{Acknowledgments}

I thank J. Cardale for arranging the export permit (no. MN 04/08323), by which the specimens were brought to Japan. Many thanks are also due to J. M. Carpenter and anonymous reviewers for critically reading the manuscript. The present study was supported by a Grant-in-Aid from the Japan Society for the Promotion of Science (no. 11833001).

\section{References}

Charnley, H. W. 1973. The value of the propodeal orifice and the phallic capsule in vespid taxonomy (Hymenoptera, Vespidae). Bulletin of the Buffalo Society of Natural Science 26: $1-79$.

Kojima, J. 1998. Larvae of social wasps (Insecta: Hymenoptera; Vespidae). Natural History Bulletin of Ibaraki University 2: 7-227.

Kojima, J. 1999a. Taxonomic notes on Australian Ropalidia Guérin-Méneville, 1831 (Hymenoptera: Vespidae, Polistinae). Entomological Science 2: 367-377.

Kojima, J. 1999b. Male genitalia and antennae in an Old World paper wasp genus Ropalidia Guérin-Méneville, 1831 (Insecta: Hymenoptera; Vespidae, Polistinae). Natural History Bulletin of Ibaraki University 3: 51-68.

Kojima, J. 1999c. A key to species and notes on distribution of the polistine genus Ropalidia Guérin-Méneville, 1831 (Hymenoptera: Vespidae, Polistinae) in Australia. Entomological Science 2: $379-390$.

Richards, O. W. 1978. The Australian social wasps (Hymenoptera: Vespidae). Australian Journal of Zoology, Supplementary Series 61: 1-132. 